\title{
Jeg er glad i jobben, men...
}

Ansatte i helsevesenet er sterkt motivert av jobben og av kollegafellesskapet. Men krevende jobb, gunstige pensjonsordninger og ønsket om mer fritid gjør at mange likevel tar ut tidligpensjon. Hva kan gjøres for å få flere til å jobbe lenger?

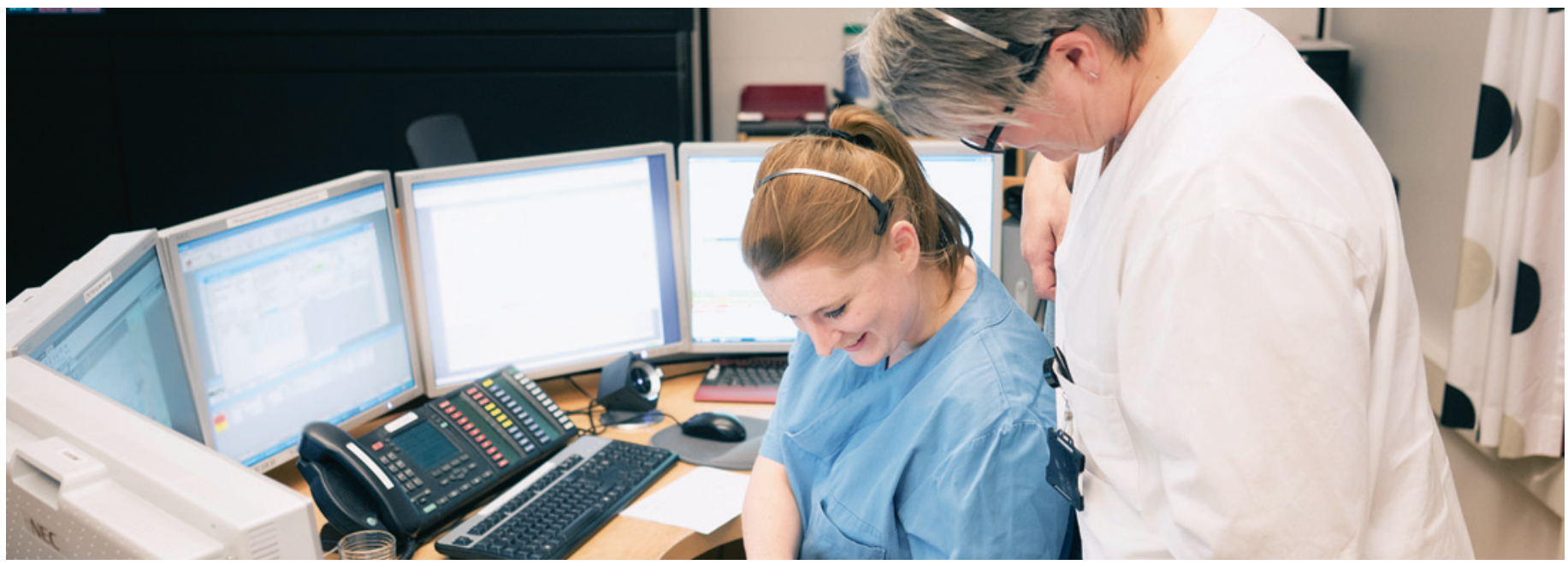

Mange av dem som pensjonerer seg tidlig fra jobber i helsevesenet, er friske og trives godt på jobben. Illustrasjonsfoto: Ole Kristian Losvik

Omtrent $40 \%$ sier at de kunne vurdert å fortsette i jobben hvis det ble gjort økonomisk gunstigere eller hvis det kunne tilrettelegges for lettere/annet arbeid, kortere reisevei eller turnusfritak. Det er også et betydelig forbedringspotensial på ledersiden hvis man ønsker å beholde seniorene i større grad enn i dag.

Det viser sluttsamtaler som 306 seniorer ved tre helseforetak i Helse Sør-Øst har hatt med sin leder. Anne Inga Hilsen i Fafo har gjennomført en analyse av sluttsamtalene. Resultatene presenteres i rapporten Jeg er glad i jobben min (1).

Målet var å evaluere seniorpolitikken i de tre helseforetakene Sykehuset Innlandet, Sykehuset Vestfold og Sykehuset Telemark. Bestillingen kom fra AFP-samarbeidsforum, som er et samarbeid mellom KLP, Spekter, Helse Sør-Øst og de tre nevnte helseforetakene om å få ned tidligpensjoneringen og heve den reelle pensjonsalderen.

\section{Så hvordan skal de klare det?}

Et av de tydeligste svarene på hva som gjør at man har stått i jobb til nå, handler om godt sosialt miljø og givende arbeidsoppgaver. «Jobben er en stor del av livet mitt. Jeg trives godt med arbeidsoppgavene og kollegene,» sier en.

En av hovedgrunnene til at mange likevel ønsker å gå av med pensjon er fordi de ønsker mer fritid og mer tid med familie og venner. «Flere og flere i min omgangskrets blir pensjonister nå. Jeg ønsker å bruke tid sammen med dem og sammen med familie. Jeg vil reise og oppleve hyggelige ting,» sier en.

En del oppgir forhold på arbeidsplassen som hovedårsaken til at de vil gå av med pensjon, som omorganisering, IT-løsninger og helsevesenets utvikling generelt. «Det er altfor stort fokus på økonomi og altfor lite fokus på pasientens tilfredshet,» sier en, mens en kollega er enda mer konkret: «DIPS.»

\section{Forbedringspotensial på ledersiden}

Flere har ikke hatt samtaler med sin leder og opplever at ingen har diskutert med dem hvilke muligheter de har for å bli i jobben. Konflikter og personalsaker kan også ende opp med aldersbegrunnede oppsigelser. «Forholdet til nærmeste leder har bidratt til valget og at det ble å gå av ved 62 år,» sier en

Mange seniorer har ønsker om fordeler som arbeidsgiver ikke kan eller vil oppfylle, som redusert stilling, turnusfritak og begrensede arbeidsoppgaver uten lønnstap. Nesten halvparten av de spurte kan imidlertid ikke fristes til å fortsette. På spørsmålet: «Er det noe som kunne vært gjort for å få deg til å stå lenger?» svarer $43 \%$ av de spurte kontant nei.

\section{Eline Feiring}

Tidsskriftet

\section{Litteratur}

1. Hilsen Al. Jeg er glad i jobben min. Fafo-rappor 2015: 03. www fafo no/index php?option $=$ com zoo\&task $=$ item\&item_id=7263\& Itemid $=923 \&$ lang $=\mathrm{nb}(2.3 .2015)$.

\section{«Jeg vil reise og oppleve hyggelige ting»}

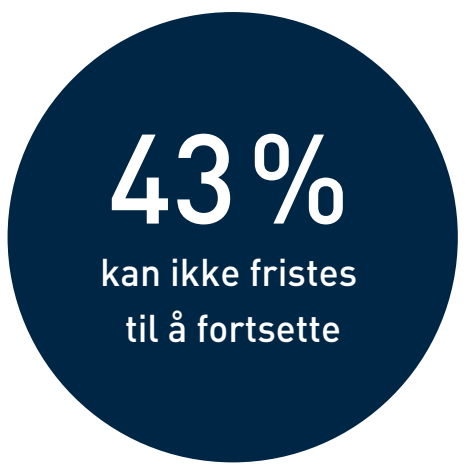

